\title{
PENGARUH PROFITABILITAS, KEBIJAKAN HUTANG DAN DIVIDEND PAYOUT RATIO (DPR) TERHADAP NILAI PERUSAHAAN
}

\author{
Oky Oktaviani \\ Program Studi S1 Akuntansi, Fakultas Ekonomi, UPN “Veteran” Jakarta \\ oky.oktav@gmail.com \\ Desmintari \\ Program Studi S1 Akuntansi, Fakultas Ekonomi, UPN “Veteran” Jakarta \\ desmintari@yahoo.com
}

\begin{abstract}
This study aimed to examine the effect of Profability, Policy Liabilities and Dividend Payout Ratio (DPR) of Company Value basic industry and chemical companies listed in Indonesia Stock Exchange period 2011 to 2014. The population in this study a number of 63 companies listed in Indonesia Stock Exchange. Data obtained from financial statements 2011 to 2014 that has been published. Obtained a total sample of 11 companies. The analysis technique used is multiple linear regression and hypothesis testing with constant 5\%. The results showed that significantly effect profitability, policy liabilities does not have a significant effect and dividend payout ratio (DPR) does not have a significant effect. The coefficient of determination $R$ square indicates 0.326 or $32.6 \%$ of explaining that the variable is explained by the variable company value and profitability, policy liability and dividend payout ratio (DPR) the remaining $67.4 \%$ is explained by other variables.
\end{abstract}

Keyword: profitability, policy liability, dividend payout ratio (DPR) and company value

\section{PENDAHULUAN}

\subsection{Latar Belakang Penelitian}

Di zaman era globalisasi ini persaingan antar perusahaan semakin meningkat, perusahaan dalam menghadapi persaingan tersebut dibutuhkan strategi untuk dapat mencapai tujuan perusahaan yang telah ditetapkan. Salah satu tujuan perusahaan adalah meningkatkan nilai perusahaan dan mensejaterahkan pemilik perusahaan, hal tersebut dapat tercipta bila perusahaan dengan tepat mengimplementasikan keputusan keuangannnya.

Perusahaan yang bergerak di sektor bisnis terdiri dari berbagai macam bidang, mulai dari yang bergerak di bidang usaha perdagangan, industri, pertambangan, pertanian, manufaktur, peternakan, perumahan, keuangan dan usaha-usaha lainnya. Masing-masing bidang usaha tersebut memiliki karakteristik tersendiri yang berbeda dan khas. Sehingga dalam pencapaian tujuan perusahaan tersebut tidaklah gampang, selalu saja terjadi hambatan dalam pelaksanaannya sehingga sebuah perusahaan harus lebih cermat lagi dalam menjalankan usahanya. Oleh karena itu suatu perusahaan harus melakukan suatu analisis yang sangat baik mengenai keputusan keuangannya sehingga kegiatan perusahaan berjalan dengan baik dan perusahaan mencapai tujuan secara efesien dan efektif, dimana setiap keputusan keuangan itu masing-masing terdapat faktor dominan yang mempengaruhinya seperti dari keputusan investasi yang disangat dipengaruhi tingkat profitabilitasnya, dan kebijakan utang yang berkaitan dengan besarnya utang, serta 
kebijakan dividen yang berkaitan dengan besarnya dividen yang dibagikan oleh perusahaan bagi pemegang saham.

Menurut Jusriani dan Rahardjo (2013) menyatakan bahwa 'profitabilitas menunjukan efektifitas atau kinerja perusahaan dalam menghasilkan keuntungan dan menjadi daya tarik utama bagi pemilik saham'. Maka tingkat pengembalian yang diharapkan oleh pemilik perusahaan akan tercermin dari profitabilitas, semakin tinggi profitabilitas, semakin tinggi nilai perusahaan.

Menurut Werner (2013, hlm.65) menjelaskan bahwa 'Dividend Payout Ratio merupakan rasio yang menggambarkan besarnya proporsi dividen yang dibagikan terhadap pendapatan bersih perusahaan'. Jadi semakin tinggi dividend payout ratio maka akan menguntungkan para pemegang saham dan sebaliknya apabila dividend payout ratio rendah maka akan merugikan para pemegang saham. Jika dividen yang dibagikan besar maka hal tersebut akan meningkatkan harga saham yang akan berakibat pada peningkatan nilai perusahaan.

Sulistiono (2010) dalam Jusriani dan Rahardjo (2013), menyatakan bahwa 'kebijakan utang bisa digunakan untuk menciptakan nilai perusahaan yang diinginkan, namun kebijakan utang juga tergantung dari ukuran perusahaan'. Artinya perusahaan yang besar akan lebih mudah mengakses ke pasar modal yang mengindikasikan bahwa perusahaan mudah untuk memenuhi sumber dana dari utang melalui pasar modal.

Menurut Taswan dan Soliha (2002) dalam Jusriani dan Rahardjo (2013), menegaskan, 'nilai perusahaan yang tinggi menjadi keinginan pemilik perusahaan, sebab dengan nilai perusahaan yang tinggi menunjukan kemakmuran pemegang saham juga tinggi'. Maka nilai perusahaan yang tinggi menunjukkan sejauh mana perusahaan dapat menjamin kemakmuran pemilik perusahaan.

Fenomena terjadi pada PT Semen Indonesia Tbk (SMGR) meraup laba bersih Rp 5,65 triliun pada tahun lalu. Jumlah itu tumbuh 3,72\% dibandingkan dengan laba bersih tahun 2013 yang senilai $\mathrm{Rp} 5,37$ triliun. Adrianus dan Thendra menargetkan harga wajar masing-masing di level Rp 17.500 per saham. Sedangkan Budi menargetkan Rp 18.000 per saham. Kemarin, tanggal 9 maret 2015 harga saham SMGR turun ke posisi Rp 14.750 per saham, dibandingkan dengan tanggal 6 maret 2015 harga saham SMGR tercatat Rp 14.950 , terjadi penurunan sebesar $1,34 \%$.

Menurut Ikbal (2011) 'profitabilitas akan berdampak terhadap peningkatan nilai perusahaan dan kemakmuran pemegang saham'. Akan tetapi yang dialami oleh PT Semen Indonesia berbanding terbalik dengan teori yang menyatakan bahwa peningkatan profitabilitas akan berdampak pada peningkatan nilai perusahaan.

Adapun tujuan dilakukannya penelitian ini adalah ingin menberikan informasi secara empiris bahwa Profitabilitas, Kebijakan Hutang dan Dividend Payout Ratio (DPR) berpengaruh signifikan terhadap Nilai Perusahaan.

\subsection{Perumusan Masalah}

Berdasarkan latar belakang penelitian yang telah diuraikan diatas, maka dapat diidentifikasikan masalah sebagai berikut:

a. Apakah secara simultan profitabilitas, kebijakan hutang dan dividend payout ratio (DPR) berpengaruh signifikan terhadap nilai perusahaan?

b. Apakah secara parisial profitabilitas mempunyai pengaruh signifikan tehadap nilai perusahaan?

c. Apakah secara parsial kebijakan hutang mempunyai pengaruh signifikan terhadap nilai perusahaan?

d. Apakah secara parsial dividend payout ratio (DPR) mempunyai pengaruh signifikan terhadap nilai perusahaan? 


\section{TINJAUAN PUSTAKA}

\subsection{Teori Keagenan (Agency Theory)}

Menurut Harmono (2011, hlm. 2) Teori keagenan dapat dikembangkan melalui hubungan antar pihak yang berkepentingan, misalnya antara kreditor sebagai principal dan manajemen sebagai agen yang membutuhkan kesepakatan kontrak utang, antara manajemen sebagai principal dan karyawan sebagai agen yang melaksanakan tugas yang didelegasikan oleh manajer senior dan hubungan lain yang menjelaskan antara principal dan agen.

\subsection{Teori Sinyal (Signaling Theory)}

Menurut Sitanggang (2013, hlm. 193) menyatakan bahwa kebijakan dividen dapat berupa sinyal (tanda) bagi investor tentang prospek perusahaan di masa datang. Artinya bahwa besar kecilnya dividend payout ratio sebagai sinyal atau tanda atas prospek laba masa datang.

\subsection{Laporan Keuangan}

Analisis laporan keuangan sangat berkaitan dengan bidang akuntansi. Kegiatan akuntansi pada dasarnya merupakan kegitan mencatat, menganalisis, menyajikan dan menafsirkan data keuangan. Laporan keuangan pada dasarnya adalah hasil dari proses akuntansi yang dapat digunakan sebagai alat komunikasi dengan pihak yang berkepentingan dengan kondisi keuangan dan hasil operasi perusahaan. Sesuai dengan PSAK no. 1 (revisi 2014) menyatakan bahwa "laporan keuangan adalah suatu penyajian terstruktur dari posisi keuangan dan kinerja keuangan suatu entitas".

Untuk mengukur kinerja perusahaan, dapat diukur dengan rasio. Analisis rasio merupakan salah satu alat analisis keuangan yang paling banyak digunakan untuk mengukur kinerja perusahaan. Berbagai rasio dapat dihitung menggunakan laporan keuangan perusahaan.

\subsection{Nilai Perusahaan}

Putra (2011, hlm. 393) menyatakan bahwa "nilai perusahaan didefinisikan sebagai persepsi investor terhadap tingkat keberhasilan perusahaan dalam mengelola sumber daya yang akan terlihat pada harga sahamnya". Mardiyati (2012), menegaskan, "pengertian nilai perusahaan dicerminkan pada kekuatan tawar menawar saham".

\subsection{Profitabilitas}

Sofyan Syafri (2011, hlm. 304) menyatakan bahwa "Profitabilitas mengambarkan kemanpuan perusahaan mendapatkan laba melalui semua kemampuan, dan sumber yang ada seperti kegiatan penjualan, kas, modal, jumlah karyawan, jumlah cabang, dan sebagainya".

Kasmir (2014, hlm. 196) menyatakan bahwa "profitabilitas merupakan rasio untuk menilai kemampuan perusahaan dalam mencari keuntungan”.

\subsection{Hutang}

Hutang merupakan salah satu sumber pembiayaan eksternal yang digunakan oleh perusahaan untuk mendanai kebutuhan dana kegiatan operasional perusahaan. Hampir semua perusahaan, baik perusahaan kecil maupun perusahaan yang besar pada umumnya untuk mendanai perusahaan yaitu dengan menggunakan hutang.

Gumanti (2011, hlm. 113) menyatakan bahwa "hutang adalah besarnya porsi utang yang ada diperusahaan jika dibandingkan dengan modal atau aset yang ada". 


\subsection{Kebijakan Hutang}

Menurut Ikbal (2011) menyatakan bahwa "kebijakan utang atau leverage menunjukkan gambaran atas penggunaan utang untuk membiayai investasi perusahaan". Menurut Mardiyati (2012) menyatakan bahwa "kebijakan hutang meru pakan kebijakan perusahaan tentang seberapa jauh sebuah perusahaan menggunakan pendanaan utang".

\subsection{Kebijakan Dividen}

Menurut Sitanggang (2013, hlm. 189) menyatakan bahwa "kebijakan dividen merupakan salah satu fungsi pokok manajemen keuangan yaitu menentukan besarnya laba bersih yang akan didistribusikan kepada pemegang saham". Menurut Harmono (2011, hlm. 12) menyatakan bahwa 'kebijakan dividen adalah persentase laba yang dibayarkan kepada para pemegang saham dalam bentuk dividen tunai'.

\subsection{Dividend Payout Ratio}

Menurut Werner (2013, hlm. 65) Dividend Payout Ratio merupakan rasio yang menggambarkan besarnya proporsi dividen yang dibagikan terhadap pendapatan bersih perusahaan. Rasio ini merupakan perbandingan antara dividen yang dibayarkan dengan laba bersih yang didapatkan dan biasanya disajikan dalam bentuk presentase. Semakin tinggi dividend payout ratio maka akan menguntungkan para pemegang saham dan sebaliknya apabila dividend payout ratio rendah maka akan merugikan para pemegang saham.

\subsection{PENGEMBANGAN HIPOTESIS}

\section{a. Pengaruh Profitabilitas terhadap Nilai Perusahaan}

Untuk mengukur kinerja perusahaan dapat diukur menggunakan rasio. Untuk menggambarkan kemampuan perusahaan dalam mencari keuntungan, menggunakan rasio profitabilitas. Werner (2013, hlm. 63) mengungkapkan bahwa rasio profitabilitas menggambarkan kemampuan perusahaan dalam mencari keuntungan. Kinerja perusahaan yang baik akan menghasilkan laba yang sehat dimasa mendatang. Sehingga akan menarik minat para investor untuk menginvestasikan uangnya atau membeli saham perusahaan tersebut, maka harga sahampun naik dan hal ini akan berpengaruh terhadap naiknya nilai perusahaan, hal tersebut diungkapkan oleh Putra (2014, hlm. 393) bahwa nilai perusahaan didefinisikan sebagai persepsi para investor terhadap tingkat keberhasilan perusahaan dalam mengelola sumber daya yang akan terlihat pada harga sahamnya.

Suatu perusahaan untuk dapat melangsungkan aktivitas operasinya, haruslah berada dalam keadaan yang menguntungkan (profitable). Tanpa adanya keuntungan akan sulit bagi perusahaan untuk menarik modal dari luar. Perusahaan yang memiliki tingkat profitabilitas yang tinggi akan diminati sahamnya oleh investor. Sehingga, dengan demikian Profitabilitas dapat mempengaruhi nilai perusahaan, (Mardiyati, 2012). Berdasarkan teori dan penelitian sebelumnya mengenai profitabilitas dan pengaruhnya terhadap nilai perusahaan sebagaimana telah dijelaskan diatas, maka dapat disusun hipotesis penelitian sebagai berikut:

\section{$\mathrm{H}_{1}$ : Profitabilitas Berpengaruh Secara Signifikan Terhadap Nilai Perusahaan}

\section{b. Pengaruh Kebijakan Hutang Terhadap Nilai Perusahaan}

Menurut Sitanggang (2012, hlm. 25) menyatakan bahwa kebijakan hutang mengukur pembiayaan perusahaan dari sumber utang. Maka semakin besar porsi utang perusahaan akan berdampak pada nilai perusahaan karena pembiayaan yang dibutuhkan oleh perusahaan dapat terpenuhi. Jika manajer memiliki keyakinan bahwa prospek perusahaan baik, dalam meningkatkan laba maka akan mendorong peningkatan harga saham 
perusahaan. Menurut teori signaling, perusahaan yang meningkatkan utang bisa dipandang sebagai perusahaan yang yakin dengan prospek perusahaan di masa yang akan datang. Investor diharapkan akan menangkap sinyal tersebut, sinyal yang mengindikasikan bahwa perusahaan mempunyai prospek yang baik di masa depan. Jadi, kita dapat menyimpulkan dari penjelasan diatas bahwasanya hutang merupakan tanda atau signal posotif dari perusahaan. Hal tersebut akan menarik minat para investor baru yang akan menginvestasikan uangnya keperusahaan tersebut, sehingga harga saham perusahaan tersebut naik, seperti yang dikemukakan oleh Putra (2014, hlm. 393) bahwa nilai perusahaan didefinisikan sebagai persepsi para investor terhadap tingkat keberhasilan perusahaan dalam mengelola sumber daya yang akan terlihat pada harga sahamnya. Maka kebijakan hutang akan berpengaruh terhadap nilai perusahaan.

Kebijakan hutang merupakan kebijakan perusahaan tentang seberapa jauh sebuah perusahaan menggunakan pendanaan hutang. Dengan adanya hutang semakin tinggi proporsi hutang maka semakin tinggi harga saham perusahaan tersebut. (Mardiyati 2012).

$\mathrm{H}_{2}$ : Kebijakan Hutang Berpengaruh Signifikan Terhadap Nilai Perusahaan

c. Pengaruh Dividend Payout Ratio (DPR) Terhadap Nilai Perusahaan

Untuk mengambarkan besarnya porsi dividen yang akan dibagikan kepada pemegang saham, dapat dihitung menggunakan rasio dividend payout ratio (DPR) Menurut Sitanggang (2013, hlm. 189) mengungkapkan bahwa kebijakan dividen merupakan salah satu fungsi pokok manajemen keuangan yaitu menentukan besarnya laba bersih yang akan didistribusikan kepada pemegang saham yang diukur dengan dividend Payout ratio. Dividen akan dibagikan apabila seluruh kebutuhan dana untuk investasi baru telah terpenuhi. Besarnya dividend per share akan berfluktusi tergantung pada laba berih dan jumlah modal untuk membiayai investasi yang layak untuk diterima. Perlu diingat bahwa investasi baru diterima apabila investasi tersebut dapat memberikan tambahan hasil yang lebih besar daripada tingkat hasil yang diminta oleh pemegang saham. Dari kebijakan demikian, pertumbuhan akan diperoleh melalui investasi baru dan pada akhirnya diharapkan akan memaksimumkan kesejahteraan pemegang saham. Sehingga akan menarik minat investor baru untuk membeli saham perusahaan yang akan mengakibatkan naiknya harga saham seperti yang di ungkapkan oleh Putra (2014, hlm. 393) nilai perusahaan dapat didefinisikan sebagai presepsi investor terhadap tingkat keberhasilan perusahaan dalam mengelola sumber daya yang akan terlihat pada harga sahamnya. Hal ini akan mengakibatkan peningkatan nilai perusahaan.

Hipotesis ini dibangun bedasarkan pijakan teori bird in the hand. Bird in the hand theory memandatang deviden tinggi adalah yang terbaik, karena investor lebih suka kepastian tentang return investasinya serta mengantisipasi risiko ketidakpastian tentang kebangkrutan perusahaan. (Ikbal, 2011).

$\mathrm{H}_{3}$ : Dividend Payout Ratio (DPR) Berpengaruh Signifikan Terhadap Nilai Perusahaan

\section{METODE PENELITIAN}

Populasi yang dipilih menjadi objek penelitian ini adalah perusahaan sektor pertambangan yang terdaftar di Bursa Efek Indonesia selama periode 2011-2014. Teknik penentuan sampel yang digunakan adalah purposive sampling. Purposive sampling yaitu pengambilan sampel yang bersifat tidak acak dan sampel dipilih berdasarkan pertimbangan-pertimbangan dan kriteria tertentu. Adapun kriteria pengambilan sampel dalam penelitian ini adalah:

a. Perusahaan manufaktur sektor industri dasar dan kimia yang terdaftar secara berturutturut di Bursa Efek Indonesia (BEI) selama periode penelitian 2011-2014.

b. Perusahaan yang tidak mempublikasikan laporan keuangan untuk tahun 2011- 2014. c. Perusahaan yang tidak menyajikan laporan keuangan dalam rupiah. 
d. Perusahaan yang tidak kimia yang mengalami kerugian pada tahun periode penelitian.

e. Perusahaan yang membayar dividen secara berturut-turut.

\subsection{TEKNIK PENGUMPULAN DATA}

Dalam penelitian ini diperoleh dari laporan keuangan pada perusahaan manufaktur yang terdaftar di BEI melalui Home Page situs Bursa Efek Indonesia yaitu ww.idx.co.id, www.duniainvestasi.com dan sumber lainnya.

\subsection{DEFINISI OPERASIONAL}

a.Variabel Dependen (Y)

Dalam penelitian ini menggunakan pengukuran menggunakan rasio Tobin's Q. Rasio ini dikembangkan oleh James Tobin (1967). Rasio ini merupakan konsep yang berharga karena menunjukkan estimasi pasar keuangan saat ini tentang nilai hasil pengembalian dari setiap dolar investasi inkremental.

Nilai perusahaan yang diproksikan dengan Tobin's Q dihitung dengan rumus sebagai berikut:

$$
\text { Tobin's } \mathrm{Q}=\frac{M V E+D E B T}{\mathrm{TA}}
$$

\section{b. Variabel Independen $(\mathrm{X})$ Profitabilitas}

Profitabilitas merupakan kemampuan perusahaan memperoleh laba dalam hubungannya dengan aset perusahaan, dengan rumus sebagai berikut:

$$
\begin{gathered}
\text { Return On Assets } \\
(\mathrm{ROA})=
\end{gathered} \quad \begin{gathered}
\text { Earning After Tax } \\
\text { Total Assets }
\end{gathered}
$$

\section{Kebijakan Hutang}

Kebijakan Hutang menunjukkan gambaran atas penggunaan utang untuk membiayai investasi perusahaan, dengan rumus sebagai berikut:

Dividend Payout Ratio (DPR)

$$
\begin{gathered}
\text { Debt Equity Ratio } \\
(\text { DER })=
\end{gathered}
$$

Dividend Payout Ratio (DPR) merupakan penyaluran hak pemegang saham, dengan rumus sebagai berikut:

$$
\begin{array}{cc}
\text { Dividend Payout Ratio } & \multicolumn{1}{c}{\begin{array}{c}
\text { Dividend Per } \\
\text { Share }
\end{array}} \\
\cline { 2 - 2 }(\mathrm{DPR})= & \text { Earning Per Share }
\end{array}
$$

\subsection{Teknik Analisis dan Uji Hipotesis}

\section{Statistik Deskriptif}

Statistik deskriptif ini adalah untuk menghubungkan dan memberikan penjelasanpenjelasan sederhana mengenai variabel-variabel penelitian, seperti jumlah variabelvariabel penelitian, nilai maksimum, minimum, rata-rata dan standar deviasi dari masingmasing variabel yang akan diteliti. 


\subsection{Uji Hipotesis}

\section{a. Uji Simultan (Uji F)}

Menurut Ghozali (2011, hlm. 98) Uji statistik F pada dasarnya menunjukkan apakah semua variabel independen atau bebas yang dimasukkan dalam model mempunyai pengaruh secara bersama-bersama terhadap variabel dependen/terikat.

\section{b. Uji Parsial (Uji t)}

Menurut Ghozali (2011, hlm. 98) Uji statistik t pada dasarnya menunjukkan seberapa jauh pengaruh satu variabel penjelas/independen secara individual dalam menrangkan variasi variabel dependen.

\section{c.Uji Koefisien Determinasi $\left(\mathbf{R}^{2}\right)$}

Menurut Ghozali (2011, hlm. 97) Koefisien determinasi $\left(\mathrm{R}^{2}\right)$ pada intinya mengukur seberapa jauh kemampuan model dalam menerangkan variabel variabel dependen.

\section{d. Analisis Regresi Liniear Berganda}

Teknik analisis data yang digunakan dalam penelitian ini untuk melakukan pengujian hipotesis adalah analisis regresi berganda.

Rumus dari regresi liniear berganda sebagai berikut :

$$
Y=\alpha+\beta_{1} X_{1}+\beta_{2} X_{2}+\beta_{3} X_{3}+e
$$

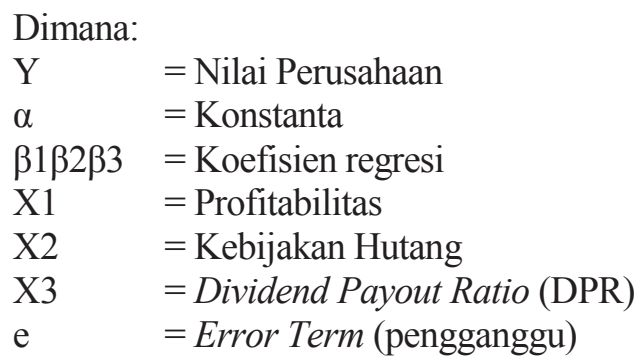

\section{HASIL DAN PEMBAHASAN}

\subsection{Statistik Deskriptif}

Data penelitian ini didasarkan pada data sekunder laporan keuangan tahunan yang diaudit dan dipublikasikan di Bursa Efek Indonesia (BEI) yang terdiri dari neraca dan laporan laba rugi serta list tanggal pelaporan keuangan dan harga saham. Sedangkan data penelitian berasal dari 11 perusahaan yang memenuhi kriteria penentuan sampel pada periode pada periode 2011 hingga 2014. Bedasarkan hasil pengolahan data menggunakan SPSS (Statistical Product and Service Solution) 20.0 diperoleh hasil perhitungan sebagai berikut:

Tabel 4

Descriptive Statistics

\begin{tabular}{lrrrrr}
\hline & $\mathrm{N}$ & \multicolumn{1}{c}{ Minimum } & \multicolumn{1}{c}{ Maximum } & \multicolumn{1}{c}{ Mean } & \multicolumn{1}{c}{ Std. Deviation } \\
\hline Profitabilitas & 44 & .001 & .321 & .11972 & .075 \\
Kebijakan Hutang & 44 & .147 & 4.011 & .78470 & .819 \\
Dividend Payout & 44 & .020 & 6.330 & .66977 & 1.027 \\
Ratio & 44 & .520 & 5.180 & 1.88659 & 1.210 \\
Nilai Perusahaan & 44 & & & & \\
Valid N (listwise) & 44 & & & \\
\hline
\end{tabular}

Dari dapat diketahui bahwa jumlah sampel yang digunakan dalam penelitian ini adalah sebanyak 44 sampel. Bedasarkan data diatas terlihat bahwa nilai minimum untuk profitabilitas adalah sebesar 0.001 dimiliki oleh PT Alumindo Light Metal Industri Tbk dan nilai maksimum untuk Profitabilitas adalah sebesar 0.321 dimiliki oleh PT Lionmesh Prima Tbk. Nilai rata-rata 
Profitabilitas adalah sebesar 0.11972 dan standard deviasi untuk Profitabilitas adalah sebesar 0.075518 , artinya perusahaan dalam penelitian ini memiliki $11.9 \%$ laba setelah pajak dari total aset.

Bedasarkan tabel diatas nilai minimum kebijakan hutang yang dimiliki PT Indocement Tunggal Prakarsa Tbk adalah sebesar 0.147 dan nilai maksimum kebijakan hutang sebesar 4.011 yang dimiliki oleh PT Alumindo Light Metal Industri Tbk. Nilai rata-rata kebijakan hutang diperoleh sebesar 0.78470 dengan nilai standard deviasi sebesar 0.819219 , artinya dengan melihat rata-rata variabel kebijakan hutang, maka rata-rata perusahaan manufaktur sektor industri dasar dan kimia yang dijadikan sebagai sampel penelitian memiliki kecenderungan sebesar $78.4 \%$ operasional perusahaan dibiayai oleh pinjaman dari luar perusahaan dibandingkan dari sumber pendanaan perusahaan.

Berdasarkan data diatas terlihat bahwa nilai minimum untuk dividend payout ratio adalah sebesar 0.020 dimiliki oleh PT Lionmesh Prima Tbk dan nilai maksimum untuk dividend payout ratio sebesar 6.330 dimiliki PT Alumindo Light Metal Industri Tbk. Nilai rata-rata dividend payout ratio sebesar 0.66977 dan nilai standar deviasi untuk dividend payout ratio sebesar 1.027335 . Artinya, seluruh perusahaan dalam penelitian ini umumnya membayar dividen sebesar $66.97 \%$ dari laba bersihnya.

Nilai minimum nilai perusahaan sebesar 0.520 yang dimiliki oleh PT Surya Toto Indonesia Tbk dan nilai maksimum nilai perusahaan sebesar 5.180 yang dimiliki oleh PT Charoen Pokphand Indonesia Tbk. Nilai rata-rata nilai perusahaan adalah sebesar 1.88659 dengan nilai standar deviasi sebesar 1.210683, artinya dengan nilai rata-rata sebesar 1.88659 menunjukkan bahwa rata-rata investasi pada perusahaan sampel menghasilkan laba yang memberikan nilai lebih tinggi daripada pengeluaran investasi.

\subsection{Uji Normalitas}

Berdasarkan hasil pengolahan data dengan menggunakan IBM SPSS (Statistical Product and Service Solution) versi 20 dan Microsoft Excel 2010, maka diperoleh hasil hasil perhitungan sebagai berikut:

Tabel. 2

\begin{tabular}{ll}
\multicolumn{2}{c}{ One-Sample Kolmogorov-Smirnov Test } \\
\hline & $\begin{array}{l}\text { Unstandardized } \\
\text { Residual }\end{array}$ \\
\hline $\mathbf{N}$ & 44 \\
Kolmogorov-Smirnov Z & .662 \\
Asymp. Sig. (2-tailed) & .773 \\
\hline
\end{tabular}

Dari tabel diatas, dapat diperoleh nilai Asymp. Sig. (2-tailed) untuk nilai perusahaan menunjukkan nilai lebih besar dari $0.05(0.773>0.05)$, sehingga dapat disimpulkan bahwa $\mathrm{H}_{\mathrm{o}}$ diterima atau data telah terdistribusi normal.

\subsection{Uji Multikolinieritas}

Berikut hasil uji Multikolinieritas dengan menggunakan bantuan aplikasi SPSS (Statistical Product and Service Solution) 20.0 for windows:

Tabel 3

Coefficients $^{\text {a }}$

\begin{tabular}{|c|c|c|}
\hline \multirow[t]{2}{*}{ Model } & \multicolumn{2}{|c|}{$\begin{array}{c}\text { Collinearity } \\
\text { Statistics }\end{array}$} \\
\hline & Tolerance & VIF \\
\hline (Constant) & & \\
\hline Profitabilitas & .600 & 1.667 \\
\hline I Kebijakan Hutang & .484 & 2.066 \\
\hline Dividend Payout Ratio & .729 & 1.371 \\
\hline
\end{tabular}

a. Dependent Variable: Nilai Perusahaan 
Dapat dilihat dari hasil uji multikolinieritas pada tabel 3 diatas dapat diketahui bahwa nilai Variance Infation Factor (VIF) dari masing-masing variabel independen yang digunakan pada penelitian ini senilai 1.667 untuk profitabilitas, 2.066 untuk kebijakan hutang, dan 1.371 untuk dividend payout ratio yang semua nilai VIF-nya kurang dari 10. Nilai Tolerance senilai 0.600 untuk profitabilitas, 0.484 untuk kebijakan hutang, dan 0.729 untuk dividend payout ratio yang semua nilai tersebut kurang dari 0.10 . Jadi, dapat disimpulkan bahwa tidak ada gejala multikolonieritas yang terjadi dalam model regresi yang digunakan.

\subsection{Uji Heterokedastisitas}

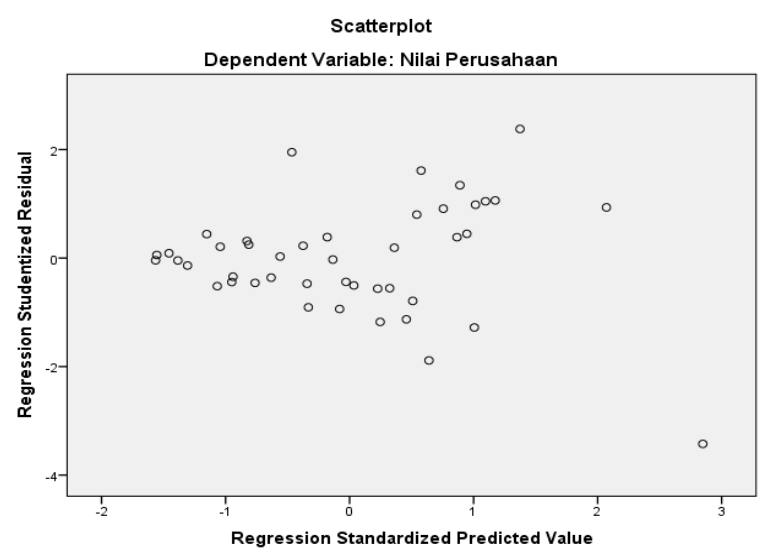

Gambar 1.Hasil Uji Heteroskedastisitas

Dari gambar diatas dapat diketahui bahwa hasil tidak adanya pola tertentu pada grafik scatterplot dan titik-titik terlihat menyebar diatas dan dibawah angka 0 pada sumbu Y, jadi tidak ada heterokedastisitas.

\subsection{Uji Autokorelasi}

Tabel 4

Model Summary ${ }^{\mathbf{b}}$

\begin{tabular}{lll}
\hline Model & Durbin-Watson & \\
\hline 1 & & 1.264
\end{tabular}

a. Predictors: (Constant), Dividend Payout Ratio, Kebijakan Hutang, Profitabilitas

b. Dependent Variable: Nilai Perusahaan

Dari tabel diatas uji autokolerasi tersebut bahwa nilai Durbin Watson (DW) sebesar 1.264. Angka tersebut berada diantara -2 sampai +2 maka dapat disimpulkan tidak terjadi autokolerasi.

\subsection{Pengujian Hipotesis}

Berikut merupakan hasil dari pengolahan data yang diolah menggunakan bantuan aplikasi SPSS (Statistical Product and Service Solution) 20.0 for windows

Uji Simultan (Uji F)

Tabel 5 Uji Simultan

ANOVA $^{\mathrm{a}}$

\begin{tabular}{llcc}
\hline Model & & F & Sig. \\
\hline $\mathbf{1}$ & Regression & 7.942 & $.000^{\mathrm{b}}$ \\
& $\begin{array}{l}\text { Residual } \\
\text { Total }\end{array}$ & & \\
& & & \\
\hline
\end{tabular}


Dengan diketahui jumlah variabel $(\mathrm{k})$ sebanyak 4, jumlah sampel (n) sebanyak 44, dan signifikansi $5 \%$, maka diperoleh $\mathrm{df} 1=\mathrm{k}-1=4-1=3$, dan $\mathrm{df} 2=\mathrm{n}-\mathrm{k}=44-3=41$. Sehingga $\mathrm{F}_{\text {tabel }}$ yaitu 2.83 , sedangkan $F_{\text {hitung }}$ 7.942. Dengan demikian $F_{\text {hitung }}>F_{\text {tabel }}, 7.942>2.83$, sehingga Ho ditolak, Ha diterima. Selain itu jika dilihat dari signifikansi yang didapat dari uji $\mathrm{F}$ pada tabel 8 diatas terlihat bahwa siginikansi sebesar $0,000<0,050$. Hal ini berarti bahwa dari kedua dasar pengambilan keputusan diatas, dapat ditarik kesimpulan bahwa Ho ditolak dan Ha diterima sehingga terbukti bahwa secara simultan Profitabilitas, Kebijakan Hutang dan Dividend Payout Ratio (DPR) mempunyai pengaruh yang signifikan terhadap nilai perusahaan.

\subsection{Uji Koefisien Determinasi $\left(\mathrm{R}^{2}\right)$}

Uji Koefisien Determinasi $\left(\mathrm{R}^{2}\right)$ dilakukan untuk mengukur seberapa jauh kemampuan variabel independen (Profitabilitas, Kebijakan Hutang dan Dividend Payout Ratio) dalam menerangkan variasi variabel dependen (Nilai Perusahaan). Berikut ini adalah hasil pengujian koefisien determinasi. Berikut ini merupakan hasil pengolahan data yang diperoleh sebagai berikut:

Tabel 6 Koefisien Determinasi

Model Summary ${ }^{\mathbf{b}}$

\begin{tabular}{llcrr}
\hline Model & R & R Square & Adjusted R Square & \\
\hline 1 & $.611^{\mathrm{a}}$ & .373 & & .326 \\
\hline
\end{tabular}

a. Predictors: (Constant), Dividend Payout Ratio, Kebijakan Hutang, Profitabilitas

b. Dependent Variable: Nilai Perusahaan

Dari tabel diatas, maka dapat disimpulkan bahwa koefisien $\mathrm{R}$ sebesar 0.611 dengan Adjusted $R$ Square yaitu 0.326 atau sebesar $32.6 \%$. Hal ini menunjukan bahwa sumbangan pengaruh variabel independen terhadap variabel dependen adalah dengan Adjusted $R$ Square sebesar $32.6 \%$ yang menandakan bahwa variabel nilai perusahaan dijelaskan oleh Profitabilitas (ROA), Kebijakan Hutang (DER) dan Dividend Payout Ratio (DPR) sebesar 32.6\%, sedangkan sisanya $67.4 \%$ dipengaruhi oleh variabel lain yang tidak dijelaskan dalam penelitian ini.

\subsection{Uji Parsial (Uji t)}

Berikut merupakan hasil dari pengolahan data yang diolah menggunakan bantuan aplikasi SPSS (Statistical Product and Service Solution) 20.0 for windows

Tabel 7 Uji Parsial Coefficients $^{\mathbf{a}}$

\begin{tabular}{rlrr}
\hline Model & & $\mathrm{t}$ & \multicolumn{1}{l}{ Sig. } \\
& & & \\
\hline & (Constant) & 1.078 & .288 \\
& Profitabilitas & 4.113 & .000 \\
& Kebijakan Hutang & .692 & .493 \\
& Dividend Payout Ratio & -.410 & .684 \\
\hline
\end{tabular}

a. Dependent Variable: Nilai Perusahaan

Dengan diketahui jumlah variabel bebas (k) sebanyak 3, jumlah sampel (n) sebanyak 44, dan signifikansi 5\%. Maka diperoleh $\mathrm{df}=\mathrm{n}-\mathrm{k}=44-4=40$. Sehingga nilai $\mathrm{t}_{\text {tabel }}$ yaitu 2.02108 . Untuk variabel profitabilitas dengan $t_{\text {hitung }} 4.113$ yang lebih besar dari $t_{\text {tabel }}$ yaitu 2.02108 , sehingga $t_{\text {hitung }}>t_{\text {tabel, }}$ maka Ho ditolak, Ha diterima. Serta dengan signifikansi yang dihasilkan yaitu 0.000 yang lebih kecil dari 0.050 sehingga benar Ho ditolak. Dengan demikian maka dapat disimpulkan bahwa secara parsial, variabel Profitabilitas memiliki pengaruh yang signifikan terhadap nilai perusahaan. 
Untuk variabel kebijakan hutang dengan $t_{\text {hitung }}$ sebesar 0.692 yang lebih kecil dari $t_{\text {tabel }}$ yaitu 2.02108, sehingga $t_{\text {hitung }}<t_{\text {tabel, }}$ maka Ho diterima, Ha ditolak. Serta dengan signifikansi yang dihasilkan yaitu 0.493 yang lebih besar dari 0,050 sehingga Ho diterima. Dengan demikian maka dapat disimpulkan bahwa secara parsial, variabel Kebijakan Hutang tidak memiliki pengaruh yang signifikan terhadap nilai perusahaan.

Untuk variabel dividend payout ratio dengan $\mathrm{t}_{\text {hitung }}$ sebesar -0.410 yang lebih kecil dari $\mathrm{t}_{\text {tabel }}$ yaitu -2.02108 , sehingga $t_{\text {hitung }}<t_{\text {tabel, }}$ maka Ho diterima, Ha ditolak. Serta dengan signifikansi yang dihasilkan yaitu 0.684 yang lebih besar dari 0,050 sehingga benar Ho diterima. Dengan demikian maka dapat disimpulkan bahwa secara parsial, variabel Dividend Payout Ratio (DPR) tidak memiliki pengaruh yang signifikan terhadap nilai perusahaan.

\subsection{Uji Regresi Berganda}

Teknik analisis data yang digunakan dalam penelitian ini untuk melakukan pengujian hipotesis adalah analisis regresi berganda. Analisis data yang digunakan ini untuk mengetahui dan menguji ada tidaknya pengaruh Profitabilitas (ROA), Kebijakan Hutang (DER) dan Dividend Payout Ratio (DPR) sebagai variabel bebas (independent variabel) terhadap Nilai Perusahaan sebagai variabel terikat (dependent variabel).

Tabel 8 Regresi Berganda Coefficients ${ }^{\mathrm{a}}$

\begin{tabular}{lrrrr}
\hline Model & \multicolumn{3}{c}{ Unstandardized Coefficients } & Standardized Coefficients \\
& $\mathrm{B}$ & Std. Error & Beta \\
\hline (Constant) & .514 & .477 & \\
Profitabilitas & 10.657 & 2.591 & .665 \\
Kebijakan Hutang & .184 & .266 & .124 \\
Dividend Payout Ratio & -.071 & .173 & -.060 \\
\hline
\end{tabular}

a. Dependent Variable: Nilai Perusahaan

Dari tabel diatas, maka dapat disajikan rumus persamaan regresi berganda sebagai berikut:

Nilai Perusahaan $=0.514+10.657$ PROFIT $+0.184 \mathrm{KH}-0.071 \mathrm{DPR}$

Dari persamaan regresi diatas dapat diinterpretasikan sebagai berikut:

a. Konstanta sebesar 0.514 artinya jika Profitabilitas $\left(\mathrm{X}_{1}\right)$, Kebijakan Hutang $\left(\mathrm{X}_{2}\right)$ dan Dividend Payout Ratio $\left(\mathrm{X}_{3}\right)$ bernilai 0 atau konstan, maka Nilai Perusahaan $(\mathrm{Y})$ diprediksi akan naik sebesar 0.514 .

b. b.Koefisien regresi variabel Profitabilitas $\left(\mathrm{X}_{1}\right)$ sebesar 10.657 artinya jika mengalami kenaikan sebesar 1 satuan maka Nilai Perusahaan (Y) akan mengalami kenaikan sebesar 10.657 dengan asumsi variabel independen lainnya tetap. Koefisien bernilai signifikan positif artinya terjadi hubungan searah antara Profitabilitas $\left(\mathrm{X}_{1}\right)$ dengan Nilai Perusahaan $(\mathrm{Y})$.

c. c.Koefisien regresi variabel kebijakan Hutang $\left(\mathrm{X}_{2}\right)$ sebesar 0.184 artinya jika mengalami kenaikan sebesar 1 satuan maka Nilai Perusahaan (Y) akan mengalami kenaikan sebesar 0.184 dengan asumsi variabel independen lainnya tetap. Koefisien bernilai signifikan positif artinya variabel Kebijakan Hutang $\left(\mathrm{X}_{2}\right)$ searah dengan Nilai Perusahaan $(\mathrm{Y})$.

d. d.Koefisien regresi variabel Dividend Payout Ratio $\left(\mathrm{X}_{3}\right)$ sebesar -0.071 artinya jika mengalami kenaikan sebesar 1 satuan maka Nilai Perusahaan (Y) akan mengalami kenaikan sebesar -0.071 dengan asumsi variabel independen lainnya tetap. Koefisien bernilai signifikan negatif artinya terjadi hubungan tidak searah antara Dividend Payout Ratio $\left(\mathrm{X}_{3}\right)$ dengan Nilai Perusahaan $(\mathrm{Y})$. 


\section{SIMPULAN, KETERBATASAN DAN KONTRIBUSI PRAKTIS}

\subsection{Simpulan}

Setelah melakukan analisis dan pengujian hipotesis mengenai pengaruh profitabilitas, kebijakan hutang dan dividend payout ratio terhadap nilai perusahaan yang terdaftar di Bursa Efek Indonesia (BEI) periode tahun 2011-2014. Hasil dan pembahasan yang digunakan sesuai dengan tujuan hipotesis yang dilakukan dengan analisis regresi linear berganda, maka dapat ditarik kesimpulan sebagai berikut :

a. Secara bersama-sama (simultan), pengaruh profitabilitas, kebijakan hutang dan dividend payout ratio berpengaruh signifikan terhadap nilai perusahaan dengan hasil 0.000 lebih kecil taraf yang ditentukan $0.05(0.000<0.05)$.

b. Secara individual (parsial) variabel profitabilitas berpengaruh signifikan positif terhadap nilai perusahaan karena memiliki nilai 0.000 , variabel kebijakan hutang tidak berpengaruh signifikan positif terhadap nilai perusahaan dengan nilai 0.493 , dan dividend payout ratio tidak berpengaruh signifikan negatif dengan memiliki nilai 0.684 .

c. Melalui uji koefisien determinasi nilai Adjusted R square diketahui sebesar 0.326. Artinya bahwa profitabilitas, kebijakan hutang dan dividend payout ratio mempunyai pengaruh 0.326 atau $32.6 \%$ terhadap nilai perusahaan, sedangkan sisanya 0.674 atau $67,4 \%$ dipengaruhi oleh variabel lain yang tidak diteliti dalam penelitian ini.

\subsection{Keterbatasan}

Hasil penelitian ini mempunyai beberapa keterbatasan diantaranya :

a. Sampel diperoleh tidak secara random tetapi melalui kriteria tertentu atau purposive sampling, pengujian hipotesis dengan menggunakan kriteria tersebut berarti hasilnya tidak untuk keseluruhan perusahaan publik yang listing di Bursa Efek Indonesia.

b. Berkaitan dengan dividend payout ratio, dimana banyak perusahaan tidak membagikan deviden secara berturut-turut sesuai dengan tahun penelitian yang digunakan, yaitu 4 tahun.

c. Peneliti hanya menggunakan 3 variabel independen, yang terdiri dari profitabilitas, kebijakan hutang dan dividend payout ratio. Penelitian ini mengabaikan faktor lainnya yang mungkin dapat mempengaruhi nilai perusahaan seperti tingkat inflasi, kondisi politik, pergerakan bilai tukar mata uang, kebijakan pemerintah dan keadaan ekonomi nasional.

\subsection{Kontribusi Praktis}

Masih banyak keterbatasan dalam penelitian. Dengan adanya keterbatasan penelitian ini berikut saran yang dapat dijadikan acuan untuk peneliti selanjutnya untuk menyempurnakan hasil penelitian tentang harga saham :

a. Manfaat teoritis

Hasil penelitian dapat memberikan implikasi untuk memperkuat hasil penelitian sebelumnya dan menjadi dasar dalam kajian berikutnya khususnya tentang profitabilitas, kebijakan hutang dan dividend payout ratio (DPR) serta pengaruhnya terhadap nilai perusahaan.

b. Manfaat praktisi

1. Bagi peneliti

Untuk peneliti selanjutnya dapat mengembangkan penelitian ini di masa mendatang dengan mengembangkan variabel lain, seperti resiko keuangan dan ukuran perusahaan. Sebaiknya tambah jumlah periode penelitian agar rentang waktunya lebih panjang dan peneliti selanjutnya diharapkan dapat menggunakan sampel dan perusahaan yang mempunyai spesifikasi berbeda, sehingga diperoleh perbandingan hasil penelitian.

2. Bagi perusahaan

Hasil penelitian ini memberikan implikasi dan kontribusi bagi praktik di dunia usaha, yaitu nilai perusahaan sebagai perwujudan kemakmuran pemegang saham sangat dipengaruhi oleh perolehan profit perusahaan.

3. Bagi investor

Agar para investor untuk memperhatikan penggunaan informasi akuntansi yang berhubungan dengan profitabilitas, kebijakan hutang dan dividend payout ratio (DPR) yang berhubungan 
dengan nilai perusahaan. Dalam mempertimbangkan memilih perusahaan dalam melakukan pengambilan keputusan yang tepat dan baik dalam investasi.

\section{Daftar Pustaka}

Ansori, M dan Denica (2010), 'Pengaruh keputusan investasi, pendanaan dan kebijakan dividen terhadap nilai perusahaan yang tergabung dalam Jakarta Islami Indeks pada Bursa Efek Indonesia', Jurnal Analisis Manajemen, vol. 4, hlm. 153-175.

Brigham, Eugene F, \& Houston, Joel F (2010a), Dasar-dasar Manajemen Keuangan, edisi 11, Salemba Empat, Jakarta.

Brigham, Eugene F, \& Houston, Joel F (2011b), Dasar-dasar Manajemen Keuangan, edisi 11, Salemba Empat, Jakarta.

Ghozali, Imam (2011), Aplikasi Analisis Multivariate dengan IBM SPSS 19, Badan Penerbit UNDIP, Semarang.

Hanafi, Mamduh (2012), Manajemen Keuangan, BPEE, Yogyakarta.

Harahap, SS (2011), Analisis Kritis atas Laporan Keuangan, Rajawali Pers, Jakarta.

Harmono, (2011), Manajemen Keuangan, Bumi Aksara, Jakarta.

Harrison, W T, Horngren, Charles T, Thomas, Bill (2013), Akuntansi Keuangan, Erlangga, Jakarta.

Hery (2012), Analisis Laporan Keuangan, Bumi Aksara, Jakarta.

Ikbal, M, Sutrisno dan Djamhuri, A (2011), 'Pengaruh profitabilitas dan kepemilikan insider terhadap nilai perusahaan dengan kebijakan utang dan kebijakan dividen sebagai variabel intervening', Simposium Nasional Akuntansi XIV Banda Aceh, Juli 2011, hlm.1-38.

Juhandi, Nendi, Sudarma, made, Aisjah, Siti (2013), 'The Effects of Internal factors and Stock Ownership Structure on Dividend Policy on Company's Value, International Journal of Businnes and Management Invention, vol. 2, November 2013, pp. 06-18.

Jumingan (2011), Analisis Laporan Keuangan, BumiAksara, Jakarta.

Jusriani, FI \& Rahardjo, Nur Shiddiq (2013), 'Analisis pengaruh profitabilitas, kebijakan deviden, kebijakan utang dan kepemilikan manajerial terhadap nilai perusahaan', Diponegoro Journal of Accountig, vol. 2, no. 2, hlm. 1-10.

Kasmir (2014), Analisis Laporan Keuangan, Rajawali Pers, Jakarta.

Mardiyati, U (2012), 'Pengaruh kebijakan dividen, kebijakan hutang dan profitabilitas terhadap nilai perusahaan', Jurnal Riset Manajemen Sains Indonesia, vol. 3, no. 1, hlm. 1-17.

Maxwell, OO \& Kehinde, EF (2012), 'Capital structure and firm value: empirical evidence from Nigeria', International Journal of Business and Sicial Science, vol. 3, no. 19, October 2012, hlm. 252-261.

Murhadi, Werner, R (2013), Analisis Laporan Keuangan, Salemba Empat, Jakarta.

Prasetyo, HA (2011), Valuasi Perusahaan, PPM, Jakarta. 
Putra, NWA (2014), 'Pengaruh Faktor Fundamentalpada Nilai Perusahaan sektor Telekomunikasi di Bursa Efek Indonesia', E-Jurnal Akuntansi Universitas Udayana, vol. 8, no. 3, hlm. 386-393.

Pura, R (2013), Pengantar Akuntansi 1 Pendekatan Siklus Akuntansi, Jakarta, Erlangga.

Putri, S (2015), Tantangan sekeras beton mengadang SMGR, http://investasi.kontan.co.id/news/tantangan-sekeras-beton-mengadang-smgr, diperoleh pada tanggal 10 maret 2015.

Qomari, R (2009), 'Teknik Penelusuran Analisis Data Kuantitatif dalam Penelitian Kependidikan', Jurnal Pemikiran Alternatif Kependidikan, vol.14, no.3, Sep-Des 2009.

Ruan, W, Gary, T \& Shiguang, M (2011), 'Managerial Ownership, Capital Structure and Firm Value: Evidence from China's Civilian-run Firms', Australasian Accounting Bisiness and Finance Journal. vol 5, hal 73-92.

Santoso, S 2010, Statistik Parametrik, PT. Elex Media Komputindo, Jakarta.

Sitanggang, J.P (2013), Manajemen Keuangan Perusahaan, Mitra Wacana Media, Jakarta.

Sumanti, C J dan Mangantar, M (2015), 'Analisis kepemilikan manajerial, kebijakan hutang dan profitabilitas terhadap kebijakan dividen dan nilai perusahaan', Jurnal EMBA, vol 3, no. 1, Maret 2015, hal 1141-1151.

Subramanyam, K. R \& Wild, John J 2014, Analisis Laporan Keuangan, Salemba Empat, Jakarta.

Sudana, IM 2011, Manajemen Keuangan Perusahaan, Teori dan Praktik, Erlangga, Jakarta.

Surjanto, D 2013, PSAK 1 s/d 59 (Exposure Draft), Diakses 16 April 2013, http://dedsur.blogspot.com/2013/04/download-psak-1-sd-35-exposure-draft.html

Wijaya, LRP \& Wibawa, BA 2010, 'Pengaruh keputusan investasi, keputusan pendanaan dan kebijakan dividen terhadap nilai perusahaan', Simposium Nasional Akuntansi XIII Purwokerto. 